\title{
DISIPLIN KERJA, MOTIVASI KERJA DAN KEPUASAN KERJA KARYAWAN HOTEL PRAMA SANUR BEACH BALI Putu Arya Gunawan ${ }^{1}$, Komang Krisna Heryanda ${ }^{2}$
}

\author{
1.2.3Universitas Pendidikan Ganesha, Singaraja \\ e-mail: aryagunawans007@gmail.com, krisna.heryanda@undiksha.ac.id
}

\begin{abstract}
Abstrak
Penelitian ini bertujuan untuk menguji: (1) Disiplin kerja dan motivasi kerja terhadap kepuasan kerja, (2) Disiplin kerja terhadap kepuasan kerja, (3) Motivasi kerja terhadap kepuasan kerja. Desain penelitian yang digunakan adalah kuantitatif kausal. Subjek penelitian ini adalah Hotel Prama Sanur Beach Bali dan untuk objek penelitiannya adalah disiplin kerja, motivasi kerja dan kepuasan kerja karyawan. Data dikumpulkan dengan kuesioner serta dengan bantuan aplikasi SPSS Versi 22.0 dianalisis dengan menggunakan analisis regresi linear berganda. Hasil penelitian menunjukkan bahwa (1) ada pengaruh secara simultan disiplin kerja dan motivasi kerja berpengaruh signifikan terhadap kepuasan kerja karyawan, (2) ada pengaruh secara parsial disiplin kerja berpengaruh positif dan signifikan terhadap kepuasan kerja karyawan, (3) ada pengaruh secara parsial motivasi kerja berpengaruh positif dan signifikan terhadap kepuasan kerja karyawan.
\end{abstract}

Kata Kunci: disiplin, motivasi, kepuasan kerja

\begin{abstract}
This study aims to examine: (1) work discipline and work motivation on job satisfaction, (2) work discipline on job satisfaction, (3) job motivation on job satisfaction. The research design used is quantitative causal. The subject of this research is Hotel Prama Sanur Beach Bali and the object of research is work discipline, work motivation and employee job satisfaction. Data were collected by means of a questionnaire and with the help of the SPSS version 22.0 application and analyzed using multiple linear regression analysis. The results showed that (1) there is a simultaneous influence of work discipline and work motivation have a significant effect on employee job satisfaction, (2) there is a partial influence of work discipline has a positive and significant effect on employee job satisfaction, (3) there is a partial effect on work motivation. positive and significant effect on employee job satisfaction.
\end{abstract}

Keywords: discipline, job satisfaction, motivation 


\section{PENDAHULUAN}

Pada era globalisasi saat ini kemajuan dan perkembangan berbagai bidang seperti pendidikan, kesehatan, politik, sosial, ekonomi dan lain-lain sangat tumbuh pesat yang berdampak pada kehidupan manusia. Manusia sebagai makhluk sosial dan individu harus memiliki keterampilan dan keahlian tersendiri agar bisa selaras dengan perkembangan jaman. Dengan adanya hal tersebut agar bisa dapat berkompetisi dan bersaing secara sehat/ kompetitif antar sesama manusia demi suatu tujuan pada seseorang tersebut. perlu adanya memupuk sikap disiplin kerja yang tinggi serta dilandasi dengan motivasi yang kuat maka apa yang diinginkan akan tercapai. Maka dari itu sama halnya terutama pada perusahaan juga menginginkan atau memiliki suatu pencapaian kerja yang baik apakah itu organisasi maupun karyawannya. Jika organisasi bisa menilai atau berbenah dari sisi tatanan atau aturan maka organisasi dalam perusahaan tersebut dapat mengelola atau memberdayakannya karyawan atau sumber daya manusia (SDM) secara optimal.

Karyawan merupakan sesuatu yang sangat berharga dan pokok pada perusahaan. Tanpa adanya karyawan perusahaan tidak akan bisa berjalan sebagaimana mestinya. Maka sumber daya manusia harus perlu diperhatikan karena juga sebagai penyumbang suatu ide atau gagasan agar bisa menghasilkan sesuatu pada perusahaan yang berupa karyawan dapat juga melaksanakan fungsinya dalam manajemen seperti perencanaan (planning), pengorganisasian (organizing), pengarahan (actuating), dan pengawasan (controlling) dan lainnya, agar perusahaan tersebut berjalan sesuai dengan rencana dan tujuannya.

Hal ini sejalan dengan pendapat menurut Rahmat (2018) bahwa manajemen sumber daya manusia merupakan suatu perencanaan, pengorganisasian, mengkoordinasikan, pelaksanaan, dan pengawasan terhadap pengadaan, pengembangan, pemberian balas jasa, pengintegrasian, pemeliharaan, dan pemisahan tenaga kerja dalam rangka mencapai tujuan organisasi. Selain itu, perusahaan bukan hanya sekedar mencari profit atau keuntungan melainkan bagaimana cara untuk memakai, mengelola dan memberdayakan sumber daya manusia yang ada pada perusahaan tersebut agar mencapai suatu yang diharapkan oleh perusahaan.

Bahwa manajemen sumber daya manusia adalah ilmu dan seni mengatur hubungan dan peranan tenaga kerja, agar efektif dan efisien membantu terwujudnya tujuan perusahaan, karyawan, dan masyarakat (Hasibuan, 2001). Hal ini dipertegas oleh (Gorda, 2004) yang merumuskan definisi manajemen sumber daya manusia adalah suatu proses kegiatan yang terdiri dari perencanaan, pengorganisasian, memimpin, dan pengendalian tentang pemanfaatan SDM secara efektif dan efisien, baik yang berkaitan dengan penarikan, pengembangan, pemeliharaan, maupun yang berkaitan dengan pemberhentian yang diarahkan untuk mencapai tujuan individual, fungsional, organisasional dan kemasyarakatan.

Manajemen sumber daya manusia sangat dibutuhkan pada perusahaan, termasuk yang bergerak di bidang pariwisata khususnya pada akomodasi perhotelan. Hotel Prama Sanur Beach Bali adalah suatu perusahaan yang bergerak memberikan jasa pelayanan kepariwisataan hotel berupa fasilitas atau sarana dan prasarana bagi tamu atau turis yang melakukan kegiatan dan berkunjung liburan ke Bali. Hotel Prama Sanur Beach Bali, beralamat di Banjar Semawang Sanur, memiliki tempat liburan yang lengkap berbintang lima, dekat dengan pesisir pantai Sanur. Dengan status hotel yang berbintang lima maka adanya pembagian kerja sesuai dengan per departemen hotel, pekerjaan yang diemban oleh masing-masing karyawan begitu banyak, ada beberapa persoalan yang terjadi pada karyawan hotel berbintang lima di sanur yakni dikarenakan ada indikasi rendahnya kepuasan kerja karyawan.

Dalam pengertian kepuasan kerja dari Robbins (1994, dalam Sugama, 2017) mengatakan bahwa seseorang tidak hanya sekedar melakukan pekerjaan, tetapi juga berhubungan setiap aspek lain, seperti interaksi dengan rekan sekerja, atasan, kebijakan organisasi, dan lingkungan kerja tertentu yang memungkinkan untuk sesuai atau sesuai dengan dirinya. Namun menurut Edison et al. (2017) kepuasan kerja adalah seperangkat perasaan karyawan tentang hal-hal yang menyenangkan atau tidak terhadap suatu pekerjaan yang mereka hadapi. Orang yang mengungkapkan kepuasan yang tinggi dalam pekerjaannya cenderung lebih produktif, 
mempunyai keterlibatan yang tinggi dan kecil kemungkinannya dalam mengundurkan diri dibandingkan dengan karyawan yang merasakan kepuasan yang kurang.

Menurut Hasibuan (2001) kepuasan kerja adalah sikap emosional yang menyenangkan dan mencintai pekerjaannya. Sikap ini tercermin oleh moral kerja, kedisiplinan, dan prestasi kerja. Berikut ini penyebab kurangnya kepuasan kerja karyawan pada hotel berbintang lima di kawasan sanur berdasarkan hasil wawancara terhadap salah satu karyawan yang menyangkut kepuasan kerja yang diantaranya. Promosi jabatan, pada pihak hotel dalam mengadakan promosi jabatan pada karyawan sudah sesuai aturan yang ada, namun ada karyawan yang akan dipromosikan jabatannya tidak ingin naik jabatan lagi karena posisinya sudah sesuai keinginannya, namun hal ini mengakibatkan lamanya perputaran atau rotasi kerja karyawan yang mengakibatkan salah satu karyawan akan merasa terhambat dan tidak pernah merasakan tempat jabatan tersebut. Rekan kerja, pada saat mengadakan rapat kerja ada yang mengutarakan pendapat salah satu karyawan diterima pendapatnya dan karyawan yang lainnya tidak diterima usulan pendapatnya hal ini yang dapat memicu adanya persaingan karena berbeda pemikiran/ persepsi. Dari keadaan tersebut pada karyawan hotel berbintang lima di kawasan sanur, untuk kepuasan kerja karyawan belum sesuai harapan yang didapatkan. Selain indikasi kepuasan kerja karyawan rendah penyebab atau indikasi lainnya adalah kurangnya disiplin kerja karyawan yang rendah.

Menurut Manoppo (2015) disiplin merupakan tindakan manajemen untuk mendorong para anggota organisasi memenuhi tuntutan berbagai ketentuan tersebut. sejalan dengan pendapat (Hasibuan, 2007) kedisiplinan adalah fungsi MSDM yang terpenting dan menjadi tolak ukur untuk mengukur/ mengetahui apakah fungsi-fungsi MSDM lainnya secara keseluruhan telah dilaksanakan dengan baik atau tidak. Oleh karena itu, dalam praktiknya bila suatu organisasi telah mengupayakan sebagian besar peraturan-peraturan yang ditaati sebagian besar karyawan, maka kedisiplinan telah dapat ditegakkan. Menurut Rivai (2003) disiplin kerja adalah suatu alat yang digunakan para manajer untuk berkomunikasi dengan karyawan agar mereka bersedia untuk mengubah suatu perilaku serta sebagai suatu upaya untuk meningkatkan kesadaran dan kesediaan seorang mentaati semua peraturan perusahaan dan norma-norma sosial yang berlaku.

Berdasar hasil wawancara awal didapatkan informasi bahwa terdapat keterlambatan kehadiran, yang diasumsikan sebagai kurangnya kedisiplinan kerja. Kehadiran, terkadang ada karyawan yang datang telat lebih dari jam kerja yang sudah distandarkan pada hotel untuk karyawan 15 menit jam kerja sudah di outlet, namun ada beberapa karyawan didalam kehadirannya yang kurang seperti alasan telat bangun tidur, macet dan lain sebagainya. Ketaatan terhadap peraturan kerja, pada saat karyawan dalam memarkirkan kendaraan tidak tertib atau tidak memakirkan kendaraan pada parkir yang sudah disediakan. Dan terutama pada karyawan housekeeping pada saat jadwal membersihkan kamar hotel yang dipesan oleh tamu belum selesai dibersihkan dan tamu tersebut komplain.

Dengan adanya keinginan bekerja pada karyawan yang dilandasi dengan kesungguhan maka motivasi kerja akan tercapai. Menurut Bemana et al. (2013) karyawan yang bermotivasi tinggi akan merasa lebih bahagia dan lebih bersedia untuk bekerja bagi organisasi. Sejalan dengan pendapat Robbins dan Coultters (1994, dalam Sugama, 2017) menyatakan motivasi sebagai kesediaan untuk melakukan tingkat-tingkat usaha tinggi untuk mencapai sasaransasaran organisasi sebagaimana dipersyaratkan oleh kemampuan usaha tersebut untuk memuaskan sejumlah kebutuhan individu. Menurut Toha (2012, dalam Manoppo, 2015) motivasi merupakan pendorong agar seseorang itu melakukan sesuatu kegiatan untuk mencapai tujuan.

Berdasar keterangan dari hasil wawancara awal didapatkan informasi bahwa adanya asumsi karyawan yang kurang terhadap motivasi kerja terdapat komponen sebagai berikut. Tanggung jawab, kurangnya kemauan dalam mengemban pekerjaan yang berlebih pada karyawan, dan karyawan tersebut melimpahkan pekerjaannya yang diemban kepada rekan kerjanya yang lain. Pengakuan orang lain, keprihatinan karyawan yang bekerja pada saat jadwal yang padat sampai lembur kerja dan upah yang diterima dari konsumen/ pelanggan hotel tidak sesuai pekerjaanya. 
Tujuan penelitian ini adalah untuk menguji seberapa pengaruhnya sebagai berikut. (1) Pengaruh disiplin kerja dan motivasi kerja terhadap kepuasan kerja karyawan pada Hotel Prama Sanur Beach Bali. (2) Pengaruh disiplin kerja terhadap kepuasan kerja karyawan pada Hotel Prama Sanur Beach Bali. (3) Pengaruh motivasi kerja terhadap kepuasan kerja karyawan pada Hotel Prama Sanur Beach Bali.

\section{KAJIAN PUSTAKA}

\section{Hubungan Disiplin Kerja terhadap Kepuasan Kerja Karyawan}

Bahwa pada karyawan apabila taat dan patuh terhadap aturan maka berarti apa yang sudah diinginkan sebelumnya sudah tercapai maka kepuasan kerja akan tinggi juga, atau apabila kepuasan kerja karyawan itu sudah tercukupi maka disiplin kerja akan dijalankan dengan baik. Hal ini sesuai dengan pendapat Hasibuan (2001) yang menyatakan bahwa "jika kepuasan kerja karyawan tinggi semakin tinggi pula disiplin kerja karyawan begitu juga bila sebaliknya". Hal ini sejalan dengan berdasarkan fakta penelitian terdahulu yang dilakukan oleh Maryadi (2012) yang menunjukkan bahwa "Adanya hubungan yang positif dan signifikan antara disiplin kerja dengan kepuasan kerja karyawan. Disiplin kerja meningkat maka kepuasan kerja karyawan juga meningkat". Berdasarkan landasan teori dan hasil penelitian sebelumnya maka hipotesis penelitian yang diajukan adalah:

$\mathrm{H}_{1}$ : Ada pengaruh disiplin kerja terhadap kepuasan kerja karyawan pada Hotel Prama Sanur Beach Bali.

\section{Hubungan Motivasi terhadap Kepuasan Kerja}

Dengan hubungan motivasi kerja dan kepuasan kerja karyawan sudah dapat dipenuhi. Jika karyawan tersebut mendapatkan semangat bekerja, apa yang dikerjakannya tersebut dapat dirasakan dan tercapai dengan baik. Atau karyawan bekerja dengan tekun dan terarah maka kepuasan kerja akan meningkat. Penjelasan tersebut juga sejalan dengan (Handono, 2015) menyatakan motivasi menyangkut reaksi berantai yaitu dari adanya kebutuhan yang dirasakan, kemudian timbul keinginan atau sasaran yang hendak dicapai dan mencari usaha untuk mencapai sasaran, serta berakhir dengan pemuasan. Hal ini sejalan dengan pendapat Kasenda (2013) dalam penelitiannya menyatakan bahwa motivasi berpengaruh secara signifikan terhadap kepuasan kerja pegawai. Menurut Gijoh (2013) penelitiannya tersebut menemukan bahwa motivasi kerja terbukti memiliki pengaruh terhadap kepuasan kerja karyawan. Berdasarkan landasan teori dan hasil penelitian sebelumnya maka hipotesis penelitian yang diajukan adalah: $\mathrm{H}_{2}$ : Ada pengaruh motivasi kerja terhadap kepuasan kerja karyawan pada Hotel Prama Sanur Beach Bali.

\section{Hubungan Disiplin Kerja dan Motivasi Kerja terhadap Kepuasan Kerja}

Jika karyawan bekerja secara tertib dan taat terhadap aturan kerja maka karyawan tersebut terarah dan dapat memberikan pemahaman dan pencerahan terhadap dirinya sendiri beserta rekan kerjanya dalam melakukan pekerjaannya dan akan timbul kepuasan tersendiri, maka dari itu disiplin kerja dan motivasi kerja berpengaruh terhadap kepuasan kerja karyawan. Hal ini sejalan dengan pendapat Robbins (1994, dalam Tampubolon et al., 2016) yang mengatakan bahwa terdapat beberapa faktor penting untuk memotivasi kepuasan kerja karyawan/ pegawai, terutama untuk membangun mental yang menantang, ganjaran yang pantas, kondisi kerja yang mendukung dan rekan kerja yang mendukung. Maka dari itu hubungan hasil pada penelitian ini sejalan dengan penelitian yang dilakukan oleh Hermansyah \& Indarti (2015) menyatakan bahwa motivasi kerja dan disiplin kerja berpengaruh signifikan secara bersamasama terhadap kepuasan. Berdasarkan landasan teori dan hasil penelitian sebelumnya maka hipotesis penelitian yang diajukan adalah:

$\mathrm{H}_{3}$ : Ada pengaruh disiplin kerja dan motivasi kerja terhadap kepuasan kerja pada Hotel Prama Sanur Beach Bali. 


\section{METODOLOGI \\ Desain Penelitian}

Bahwa penelitian ini dilakukan untuk mengetahui pengaruh disiplin kerja $\left(\mathrm{X}_{1}\right)$ dan motivasi kerja $\left(\mathrm{X}_{2}\right)$ terhadap kepuasan kerja karyawan pada Hotel Prama Sanur Beach Bali. Variabel dari penelitian ini ada dua yaitu variabel bebas sebagai variabel yang mempengaruhi variabel terikat, sedangkan variabel terikat sebagai variabel yang dipengaruhi karena adanya variabel bebas. Untuk penelitian ini variabel bebasnya disiplin kerja dan motivasi kerja sedangkan variabel terikatnya kepuasan kerja karyawan.

Bahwa berdasarkan pada masalah penelitian ini menggunakan metode kuantitatif kausal yaitu mengetahui seberapa pengaruh variabel satu dengan yang lainnya. Penelitian kuantitatif kausal terdiri dari beberapa tahapan yaitu (1) merumuskan masalah, (2) mengkaji teori, (3) merumuskan hipotesis, (4) mengumpulkan data, (5) mengolah data, (6) menarik kesimpulan dan saran.

Bahwa untuk penelitian ini yang sebagai penentu subjeknya yaitu karyawan Hotel Prama Sanur Beach Bali. Dan untuk objek penelitiannya adalah disiplin kerja dan motivasi kerja serta kepuasan kerja karyawan pada Hotel Prama Sanur Beach Bali. Bahwa pada penelitian ini menggunakan sampel. Menurut Sugiyono (2017) sampel adalah bagian dari jumlah dan karakteristik yang dimiliki oleh populasi. Penelitian ini memakai model probability sampling yaitu dengan menggunakan teknik simple random sampling, yang dapat diartikan sebagai penggunaan anggota sampel yang ada pada populasi yang dipakai secara acak tanpa memandang tingkatan atau strata. Maka dari itu sampel yang akan dipakai pada penelitian ini adalah jumlah total karyawan Hotel Prama Sanur Beach Bali sebanyak 419 orang. Dengan menggunakan rumus Slovin: $n=\frac{N}{\left(1+N e^{2}\right)}=\frac{419}{\left(1+419.0,1^{2}\right.}=80.73$ maka dibulatkan $=81$. Maka dari itu jumlah sampel yang dibutuhkan adalah 81 karyawan.

Bahwa untuk metode dan pengumpulan data yang akan digunakan dalam penelitian ini berupa: kuesioner. Maka dari itu akan dijelaskan sebagai berikut: Menurut Sugiyono $(2017 ; 142)$ kuesioner merupakan teknik pengumpulan data yang dilakukan dengan cara memberi seperangkat pertanyaan atau pernyataan tertulis kepada responden untuk dijawabnya. Maka dapat disimpulkan kuesioner adalah seperangkat pertanyaan yang harus dijawab oleh seseorang responden untuk mengisi angket soal dan jawaban yang sesuai situasi dan keadaan yang dirasakan oleh seseorang. Data yang didapat dari kuesioner adalah tanggapan dari responden yang berupa pertanyaan disiplin kerja dan motivasi kerja serta kepuasan kerja yang dicapai atau dirasa oleh karyawan. Jawaban yang ditentukan berdasarkan skala ukur ordinal.

Dalam sebuah kuesioner penelitian harus memiliki ketentuan uji dari instrumen penelitian berupa uji validitas dan uji reliabilitas, untuk kriteria-kriteria pengujian validitas instrumen dapat diuraikan sebagai berikut. (1) item dikatakan valid apabila $p$-value<alpha (a) 0.05 maka item instrumen tersebut dinyatakan valid. (2) item instrumen dikatakan tidak valid apabila $p$ value >alpha ( $\alpha) 0.05$ maka item instrumen tersebut dinyatakan tidak valid. Sedangkan untuk instrumen dikatakan handal (reliabel) apabila memiliki crobanch's alpha lebih dari 0,60. Maka dari itu uji reliabilitas adalah pengujian data yang dilakukan secara berulang-ulang agar menghasilkan data yang sama atau yang bersifat andal. Pengolahan data ini dengan menggunakan bantuan program Statistical Product and Service Solutions (SPSS) 22.0 for windows.

\section{Metode dan Teknik Analisis Data}

Metode yang digunakan dalam penelitian ini analisis regresi linear berganda untuk mengetahui seberapa pengaruh simultan dan parsial pada disiplin kerja dan motivasi kerja terhadap kepuasan kerja karyawan pada Hotel Prama Sanur Beach Bali. Menurut Sugiyono (2017; 275). Persamaan regresi untuk dua prediktor adalah menggunakan rumus sebagai berikut: $Y=a+b_{1} \mathrm{X}_{1}+b_{2} \mathrm{X}_{2}$

Keterangan:

$\mathrm{Y}=$ Kepuasan Kerja (Variabel Dependen/ Terikat)

$\alpha=$ Konstanta 
$\beta_{1}=$ Koefisien regresi $X_{1}$

$\beta_{2}=$ Koefisien regresi $X_{2}$

$\mathrm{X}_{1}=$ Variabel Disiplin Kerja

$\mathrm{X}_{2}=$ Variabel Motivasi Kerja

Data yang didapat sebelum diolah dengan memakai analisis regresi linear berganda. Maka dari itu teknik awal yang dilakukan dengan menguji asumsi klasik seperti uji normalitas data, uji multikolinearitas, uji heteroskedastisitas dan lain sebagainya.

\section{HASIL DAN PEMBAHASAN} Hasil

Deskripsi data yang dilakukan pada penelitian ini mencakup subjek penelitian yang berasal dari kuesioner yang berdasarkan pernyataan dari responden yaitu karyawan Hotel Prama Sanur Beach Bali yang berjumlah 81 karyawan yang diambil berdasarkan metode sampel yang dikarenakan jumlah populasi yang sangat luas dengan total keseluruhan karyawan 419 orang. Sebelum untuk data yang akan diolah terlebih dahulu dengan menggunakan pengujian asumsi klasik meliputi: (1) uji normalitas, (2) uji multikolinearitas, (3) uji heteroskedastisitas.

Hipotesis pertama adalah untuk menguji secara parsial antara variabel disiplin kerja $\left(\mathrm{X}_{1}\right)$ terhadap kepuasan kerja karyawan. Untuk hasil uji regresi linear berganda. Maka dapat diketahui nilai t sebesar 3,683 yang diperoleh pada variabel disiplin kerja dengan taraf nilai signifikan atau $p$-value sebesar $0,000<\alpha=0,05$ dapat diartikan Ho ditolak. Maka dapat dijelaskan terdapat pengaruh secara parsial/ sendiri-sendiri untuk variabel disiplin kerja berpengaruh positif dan signifikan terhadap kepuasan kerja karyawan.

Hipotesis kedua adalah untuk menguji secara parsial antara variabel motivasi kerja $\left(\mathrm{X}_{2}\right)$ terhadap kepuasan kerja karyawan. Untuk hasil uji regresi linear berganda. Maka didapatkan nilai t sebesar 6,051 yang diperoleh pada variabel motivasi kerja untuk taraf signifikan variabel motivasi kerja sebesar $0,000<\alpha=0,05$ maka dapat diartikan Ho ditolak yang dimaksud yaitu ada pengaruh positif dan signifikan variabel motivasi kerja terhadap kepuasan kerja karyawan.

Hipotesis ketiga adalah untuk menguji secara simultan antara variabel disiplin kerja $\left(\mathrm{X}_{1}\right)$ dan motivasi kerja $\left(\mathrm{X}_{2}\right)$ terhadap kepuasan kerja $(\mathrm{Y})$. Maka untuk hasil uji regresi linear berganda. Maka dapat dijelaskan bahwa nilai F hitung memiliki nilai sebesar 154,001 dengan bernilai taraf signifikan sebesar 0,000<0,05. Bahwa dapat kesimpulannya Ho ditolak, yang dimaksud adalah terdapat pengaruh secara simultan/ bersama-sama, keseluruhan antara variabel disiplin kerja dan motivasi kerja berpengaruh signifikan terhadap kepuasan kerja karyawan.

Bahwa interpretasi yang dihasilkan dari persamaan regresi dengan metode analisis regresi linear berganda akan dijelaskan sebagai berikut. Bahwa konstanta (a) nilai konstanta sebesar 0,988 . Sedangkan nilai koefisien disiplin kerja $\left(\beta_{1}\right)$ sebesar 0,353 . Dan untuk nilai koefisien motivasi kerja $\left(\beta_{2}\right)$ sebesar 0,576 . Dari hasil pemaparan nilai koefisien masing-masing variabel tersebut dalam bentuk analisis regresi linear berganda, maka akan diterangkan sebagai berikut: $Y=0,988(\alpha)+0,353\left(X_{1}\right)+0,576\left(X_{2}\right)$. Bahwa akan dijelaskan mengenai analisis regresi linear berganda yaitu:

Nilai konstanta sebesar 0,988 dapat diartikan sebagai variabel disiplin kerja dan motivasi kerja menghasilkan nilainya sama dengan nol, maka kepuasan kerja karyawan Hotel Prama Sanur Beach Bali memiliki nilai 0,988. Nilai koefisien disiplin kerja $X_{1}$ sebesar 0,353 berarti bahwa ada pengaruh positif antara variabel disiplin kerja dengan kepuasan kerja. Jika variabel disiplin kerja naik satu satuan maka untuk variabel kepuasan kerja memperoleh peningkatan sebesar 0,353 , maka dari itu kepuasan kerja menjadi 1,341. Dengan ketentuan bahwa variabel lainnya tetap. Nilai koefisien motivasi kerja $\mathrm{X}_{2}$ sebesar 0,576 berarti bahwa ada pengaruh positif antara variabel motivasi kerja dengan kepuasan kerja. Jika variabel motivasi kerja naik satu satuan maka untuk variabel kepuasan kerja memperoleh peningkatan sebesar 0,576, maka dari itu kepuasan kerja menjadi 1,564. Dengan ketentuan bahwa variabel lainnya tetap. 


\section{Pembahasan Hasil Penelitian \\ Pengaruh Disiplin Kerja Terhadap Kepuasan Kerja Karyawan}

Dari hasil penelitian yang dilakukan bahwa adanya pengaruh positif dan signifikan disiplin kerja terhadap kepuasan kerja karyawan pada Hotel Prama Sanur Beach Bali sejalan dengan teori yang dikemukakan oleh Sukirman (2011) mengemukakan bahwa disiplin kerja yang baik bisa disebabkan karena menyukai pekerjaan dan lingkungan kerjanya. kurang puasnya karyawan dalam bekerja dapat ditimbulkan akibat kondisi kerja kurang memadai, kurangnya kesempatan berprestasi, serta kurang mendapatkan pengakuan dari atasan. Hal ini sejalan dengan Maryadi (2012) yang menunjukkan bahwa adanya hubungan yang positif dan signifikan antara disiplin kerja dengan kepuasan kerja karyawan. Disiplin kerja meningkat maka kepuasan kerja karyawan juga meningkat. Namun pada karyawan hotel berbintang lima di kawasan sanur, dalam segi kedisiplinan masih ada karyawan yang datang telat kerja, memarkirkan kendaraan tidak rapi, serta memakai seragam kerja tidak sesuai jadwal yang ditetapkan.

\section{Pengaruh Motivasi Kerja Terhadap Kepuasan Kerja Karyawan}

Hasil dari penelitian selanjutnya yaitu pengaruh motivasi kerja terhadap kepuasan kerja karyawan pada Hotel Prama Sanur Beach Bali. Dengan motivasi kerja yang tinggi maka akan menambah kepuasan kerja karyawan serta dimana motivasi kerja sangat berpengaruh sekali terhadap kepuasan kerja karyawan. Hal ini sejalan dengan pendapat Rizwan et al (dalam Poniasih \& Dewi, 2015) yang menyimpulkan bahwa motivasi merupakan salah satu faktor yang dapat meningkatkan kepuasan kerja karyawan. Sejalan menurut McClelland (dalam Sugama, 2017:21) motivasi adalah segala sesuatu yang mendorong seseorang pegawai melaksanakan tugas-tugasnya untuk mencapai tujuan yang diinginkan. Pada penelitian tersebut juga didukung oleh Brahmasari \& Suprayetno (2008) menunjukkan bahwa terdapat hubungan positif antara motivasi dengan kepuasan kerja. Sejalan dengan pendapat Sugama (2017) hasil analisis mengenai pengaruh motivasi kerja terhadap kepuasan kerja menunjukkan bahwa motivasi berpengaruh positif dan signifikan terhadap kepuasan kerja pegawai artinya semakin meningkatnya motivasi maka kepuasan kerja pegawai semakin meningkat. Dilihat dari karyawan hotel berbintang lima di kawasan sanur, motivasi karyawannya yang masih ada kurang dikarenakan oleh faktor tugas atau emban pekerjaan yang dijalankan oleh karyawan masih belum memiliki cukup tanggung jawab, kemampuan yang dimiliki karyawan belum bisa mencapai target yang diinginkan/ prestasi yang diinginkan, penilaian dari pimpinan maupun rekan kerja tidak sesuai yang diharapkan, mengembangkan jabatan/ karier dihambat oleh masa kerja, keterampilan yang masih belum memadai.

\section{Pengaruh Disiplin Kerja Dan Motivasi Kerja Terhadap Kepuasan Kerja Karyawan}

Berdasarkan hasil dari penelitian yang telah dilakukan dengan menguji variabel disiplin kerja dan motivasi kerja terhadap kepuasan kerja karyawan pada Hotel Prama Sanur Beach Bali bahwa ada pengaruh secara signifikan. Dengan meningkatnya disiplin kerja dan motivasi kerja maka tentu akan memberikan dampak pada kepuasan kerja karyawan. Hal ini sejalan dengan penelitian yang dilakukan oleh Robbins (1994, dalam Tampubolon et al., 2016) yang mengatakan bahwa terdapat beberapa faktor penting untuk memotivasi kepuasan kerja pegawai, terutama untuk membangun mental yang menantang, ganjaran yang pantas, kondisi kerja yang mendukung dan rekan kerja yang mendukung. Pendapat tersebut sejalan dengan Mardiono (2014) yang menyatakan motivasi dan disiplin kerja berpengaruh signifikan terhadap kepuasan kerja karyawan. Namun untuk karyawan pada hotel berbintang lima di sanur tersebut, dalam memenuhi keinginan dan harapan bekerja yang belum optimal disebabkan oleh faktor internal yaitu belum bisa mengelola dan mengembangkan kemampuan diri sendiri dan faktor eksternal yaitu belum bisa memenuhi keinginan pihak hotel/ perusahaan secara baik.

Bahwa didalam penelitian yang dilakukan masih ada keterbatasan penelitian yang dilakukan yang disebabkan oleh karena penelitian yang dilakukan hanya satu hotel saja yang dilakukan observasi. Maka dari itu tidak dapat membedakan dan membandingkan atau menggeneralisasi dengan hotel yang lainnya, populasi jumlah karyawan hotel sangat banyak 
kedepannya perlu memakai penelitian tersebut dengan menggunakan cara metode mengambil per departemen. Variabel yang diteliti masih terbatas hanya menggunakan variabel disiplin kerja dan motivasi kerja yang diharapkan dapat mencari variabel yang lain bervariasi atau dapat terhubung dan sejalan dapat mempengaruhi variabel kepuasan kerja karyawan.

\section{Implikasi}

Dalam penelitian ini mendapatkan hasil bahwa pengaruh disiplin kerja dan motivasi kerja berpengaruh secara simultan maupun parsial pada kepuasan kerja karyawan pada Hotel Prama Sanur Beach Bali. Maka dari itu akan dijelaskan implikasi dari penelitian ini sebagai berikut:

(1) Pada Hotel Prama Sanur Beach Bali diharapkan dapat meningkatkan kualitas disiplin kerja karyawannya agar karyawan yang bekerja dapat memupuk dan memiliki nilai kedisiplinan, ketaatan (integritas). Namun ada beberapa permasalahan mengenai kedisiplinan kerja karyawan pada hotel berbintang lima di kawasan sanur tersebut yang disebabkan oleh 1) kurangnya kehadiran akan kesadaran dalam memperhatikan hari/ jam kerja karyawan tersebut disaat bekerja, yang berakibat tingkat partisipasi keinginan untuk bekerja karyawan rendah, dan akan semaunya karyawan menentukan jam untuk bekerja atau datang. 2) disebabkan kurangnya karyawan dalam mentaati peraturan kerja yang ada karena aturan kerja yang bersifat longgar. Yang mengakibatkan kurangnya kedisiplinan kerja karyawan pada hotel berbintang lima di kawasan sanur terutama didalam memakai busana/ berpakaian yang kurang rapi dan tidak terjadwal. 3) disebabkan ketentuan standar kerja yang minim terkadang ada karyawan yang melakukan pekerjaan tidak sesuai standar operasi prosedur yang mengakibatkan kriteria nilai-nilai yang ada pada karyawan terhadap pekerjaannya akan menurun. 4) disebabkan tingkat kewaspadaan kerja yang rendah karyawan berkerja berpatokan terhadap mengejar kebutuhan pelanggan dan kurang memperhatikan dirinya sendiri atau karyawan tersebut dan hotel, maka berakibat kehati-hatian dan ketelitian pada karyawan tersebut terancam. 5) disebabkan kurangnya karyawan bekerja secara etis atau sesuai norma-norma yang berlaku pada hotel, maka akan berakibat kepercayaan dan menjunjung nilai kebersamaan, dan beretika akan dipandang sebagai formalitas.

(2) Pada Hotel Prama Sanur Beach Bali. Agar dapat meningkatkan motivasi kerja perlunya diperhatikan karyawan tersebut. Namun masih ada beberapa karyawan belum tergugah dalam menjalankan pekerjaan. Yang disebabkan oleh 1) tanggung jawab yang diterima oleh karyawan tidak sepenuhnya karyawan tersebut mengemban pekerjaannya yang diberikan, tanggung jawabnya tersebut dan dilimpahkan kepada rekan kerjanya yang lain yang dapat mengakibatkan adanya tumpang tindih antar rekan kerja dan renggangnya hubungan rekan kerja. 2) disebabkan prestasi yang diraih oleh karyawan hotel masih rendah karena minimnya karyawan yang berkerja memiliki predikat kerja yang memuaskan yang dapat mengakibatkan pencapaian penilaian kinerja karyawan hanya di rata-rata standar kerja. 3) disebabkan oleh pengakuan orang lain kurangnya rasa menghargai satu sama lain atau adanya rasa persaingan antar individu yang mengakibatkan kepuasan salah satu seorang karyawan tersebut tidak terpenuhi karena pekerjaan yang sudah dijalankan secara maksimal tidak dapat penghargaan/ reward yang sepantasnya yang dikerjakan. 4) disebabkan oleh kemungkinan pengembangan karyawan terhambat karena memandang senior dan junior, dari pengalaman kerja yang sudah lama dan senior diatas sepuluh tahun akan mudah untuk naik posisi atau jabatan namun untuk yang junior atau karyawan yang bekerja sepuluh tahun kebawah akan terhambat, hal tersebut akan mengakibatkan keterbatasan karyawan baru pada hotel berbintang lima di kawasan sanur, serta akan terhambat di dalam mengembangkan pekerjaan dan keterampilan yang dimiliki. 5) kemajuan yang dimiliki karyawan yang masih tergolong rendah atau cara berpikir karyawan untuk melangkah ke depan masih belum optimal disebabkan ada beberapa karyawan hanya berpatokan pada kemampuan yang dimilikinya hanya sebatas sedang yang dimiliki, dan tidak mengembangkan atau meningkatkan lagi kompetensinya. 


\section{SIMPULAN DAN SARAN \\ Simpulan}

Berdasarkan hasil penelitian dan pembahasan yang sudah ada, maka akan beberapa kesimpulan yang dijabarkan sebagai berikut.

(1) Disiplin kerja dan motivasi kerja berpengaruh secara signifikan terhadap kepuasan kerja karyawan pada Hotel Prama Sanur Beach Bali, diindikasikan apabila adanya landasan kerja karyawan didalam membangun disiplin kerja dan motivasi kerja yang tinggi maka kepuasan kerja akan tercapai dan terpenuhi pada karyawan tersebut.

(2) Disiplin kerja berpengaruh secara positif dan signifikan terhadap kepuasan kerja karyawan pada Hotel Prama Sanur Beach Bali, diindikasikan apabila disiplin kerja karyawan yang diterapkan sesuai dengan ketentuan peraturan yang berlaku maka kepuasan kerja karyawan akan sebagai dedikasi.

(3) Motivasi kerja berpengaruh secara positif dan signifikan terhadap kepuasan kerja karyawan pada Hotel Prama Sanur Beach Bali, diindikasikan apabila motivasi kerja karyawan terbangun maka kepuasan kerja akan meningkat.

\section{Saran}

berikut:

Berdasarkan hasil dari pembahasan, simpulan, dan saran, maka akan dijelaskan sebagai

(1) Pada pihak Hotel Prama Sanur Beach Bali

Bahwa perlunya membangun kepuasan kerja agar terciptanya disiplin kerja dan motivasi kerja yang memadai. Dengan meningkatkan kedisiplinan kerja karyawan maka akan membentuk karakter kepribadian positif seperti taat terhadap aturan jam kerja seperti tidak mengundur-undur waktu kerja dan tidak hadir serta bolos kerja, taat pada hari kerja seperti disaat karyawan kerja harus bekerja sesuai dengan hari normal kerja dan disaat libur kerja sesuai dengan cuti, libur bersama, libur nasional, keagamaan dll, taat berpakaian atau berbusana kerja yang sesuai jadwal kerja serta dengan meningkatkan motivasi kerja maka akan membentuk dorongan kerja karyawan akan merasa tergugah untuk menampilkan kemampuan dan keterampilannya seperti karyawan dapat membantu atau memberikan sumbangan hasil kerjanya yang lebih baik demi nama instansi hotel yang diembannya, dan dapat memberikan contoh atau sebagai cerminan pada karyawan tersebut mampu untuk melakukan pekerjaannya dan ditiru atau diikuti jejak keterampilan yang dimiliki oleh karyawan yang lainnya.

(2) Bagi peneliti selanjutnya

Apabila peneliti selanjutnya ingin memakai penelitian yang serupa dengan menggunakan variabel disiplin kerja, motivasi kerja, dan kepuasan kerja karyawan diharapkan di dalam untuk mengembangkan penelitian ini dengan menggunakan populasi dan sampel yang lebih luas agar hasil penelitian yang dilakukan teruji kehandalannya, disamping itu juga agar diharapkan untuk menguji variabel lain yang diduga kuat dapat mempengaruhi kepuasan kerja karyawan, prestasi kerja karyawan, produktivitas kerja karyawan dan kinerja karyawan seperti budaya organisasi, stres kerja, beban kerja, konflik kerja, tingkat pendidikan.

\section{DAFTAR PUSTAKA}

Bemana, S., MOradi, H., Ghasemi, M., \& Taghavi, S. M. (2013). The Relationship Among Job Stress and Job Satisfaction in Municipality Personnel in Iran. World Applied Sciences Journal, 22(2), 233-238.

https://doi.org/http://dx.doi.org/10.5829/idosi.wasj.2013.22.02.3640

Brahmasari, I. A., \& Suprayetno, A. (2008). Pengaruh Motivasi Kerja, Kepemimpinan dan Budaya Organisasi Terhadap Kepuasan Kerja Karyawan Serta Dampaknya pada Kinerja Perusahaan (Studi Kasus pada PT. Pei Hai International Wiratama Indonesia). Jurnal Manajemen Dan Kewirausahaan, 10(10), 124-135. 
Edison, A., Anwar, Y., \& Komariyah, I. (2017). Manajemen Sumber Daya Manusia (2nd ed.). Alfabeta.

Gijoh, R. (2013). Motivasi, Kompensasi dan Budaya Kerja Pengaruhnya Terhadap Kepuasan Kerja Karyawan Outsourcing Pada Hotel Peninsula Manado. Jurnal EMBA2, 1(4), 19631973.

Gorda, I. G. N. (2004). Manajemen Sumber Daya Manusia. STIE Satya Darma.

Handono, I. (2015). Pengaruh Kedisiplinan dan Motivasi Kerja terhadap Kinerja Guru IPS. JPPI, $7(10), 1021-1147$.

Hasibuan, M. (2001). Manajemen Sumber Daya Manusia : pengertian dasar, pengertian, dan Masalah. PT. Toko Gunung Agung.

Hasibuan, M. (2007). Manajemen Sumber Daya Manusia (9th ed.). PT Bumi Aksara.

Hermansyah, \& Indarti, S. (2015). Pengaruh Motivasi Dan Disiplin Kerja Terhadap Kepuasan Dan Kinerja Karyawan PT.Peputra Supra Jaya Pekanbaru. Jurnal Tepak Manajemen Bisnis, 7(2), 165-178.

Kasenda, R. (2013). Kompensasi dan Motivasi Pengaruhnya terhadap Kinerja Karyawan pada PT. Bangun Wenang Beverages Company Manado. Jurnal EMBA, 1(3), 853-859.

Manoppo, R. (2015). Pengaruh Disiplin Kerja, Motivasi kerja, Dan Pengembangan Karir Terhadap Kepuasan Kerja Pada TVRI Sulawesi Utara. Jurnal EMBA, 3(3), 1220-1231.

Mardiono, D. (2014). Pengaruh Motivasi dan Disiplin Kerja Terhadap Kepuasan Kerja Karyawan. Jurnal IImu \& Riset Manajemen, 3(17), 68-77.

Maryadi. (2012). Pengaruh Budaya Organisasi, Kompensasi, dan Kepuasan Kerja Terhadap Disiplin Kerja Guru SD di Kecamatan Tengaran Kabupaten Semarang. Jurnal Manajemen Pendidikan Program Pascasarjana IKIP PGRI Semarang, 1(2), 177-188.

Poniasih, N. L. G., \& Dewi, A. A. S. K. (2015). Pengaruh Motivasi Kerja, Komunikasi Dan Stres Kerja Terhadap Kepuasan Kerja Karyawan. E-Jurnal Manajemen Unud, 4(6), 1560-1573.

Rahmat, Y. (2018). Pengaruh Tingkat Pendidikan, Motivasi Kerja, Dan Disiplin Kerja Terhadap Kinerja Guru di SMPN 1 Kecamatan Pangkalan Koto Baru Kabupaten 50 Kota. Jurnal Daya Saing, 4(1), 89-93.

Rivai, V. (2003). Manajemen Sumber Daya Manusia untuk perusahaan. PT. Raja Grafindo Persada.

Sugama, I. D. G. Y. (2017). Pengaruh Stres kerja Dan Motivasi Terhadap Kinerja Pegawai Melalui Kepuasan Kerja Sebagai Variabel Intervening Pada Unit Layanan Pengadaan (ULP) Provinsi Bali. Jagadhita: Jurnal Ekonomi \& Bisnis, 4(1), 11-26.

Sugiyono. (2017). Metode Penelitian Kuantitatif, Kualitatif, Dan R\&D. Alfabeta.

Sukirman. (2011). Hubungan Kepuasan Kerja dengan Disiplin Kerja Karyawan Bagian Produksi PT. Bitratex Semarang. Jurnal Sosial Dan Budaya, 4(1), 13-23.

Tampubolon, J. I., Isyandi, B., \& Indarti, S. (2016). Pengaruh Disiplin Dan Motivasi Karyawan 
Terhadap Kepuasan Kerja Dan Kinerja Karyawan Pada Pabrik Kelapa Sawit PT.

Perkebunan Nusantara V Unit Bisnis Sungai Galuh. Jurnal Ekonomi, 24(4), 66-82. 